\title{
BATA RINGAN DARI CAMPURAN LIMBAH SEKAM PADI DAN SERBUK GERGAJIAN
}

\author{
Zainal Abidin, Sunardi dan Violet \\ Fakultas Kehutanan, Universitas Lambung Mangkurat \\ Email: zainal_abidinyns@yahoo.co.id
}

\begin{abstract}
ABSTRAK
Kecamatan Tatah Makmur Kalimantan Selatan merupakan salah satu lumbung beras di Kalimantan Selatan. Pada tahun 2013 luas tanam di Kecamatan Gambut sebesar 10.076 ha sehingga luas panennya menjadi 9,714 ha dengan produksi sebanyak 40.566 ton atau dengan rata-rata produksi $41,76 \mathrm{kw} / \mathrm{ha}$. Limbah dari penggilingan padi berupa sekam padi menjadi masalah bagi masyarakat terutama masalah lingkungan dan kesehatan. Salah satu solusi untuk memanfaatkan limbah sekam padi menjadi produk yang bernilai jual adalah pembuatan bata ringan yang ramah lingkungan sehingga kebutuhan akan bata ringan dapat terpenuhi. Kegiatan Ipteks bagi Masyarakat bertujuan untuk menambah pengetahuan dan keterampilan petani dalam memanfaatkan limbah pertanian berupa sekam padi dengan campuran serbuk gergajian menjadi produk bata ringan. Masyarakat yang menjadi mitra pada kegiatan Ipteks bagi Masyarakat (IbM) adalah Kelompok Masyarakat RT. 6 dan Kelompok Tani "Bina Desa" yang berlokasi di Desa Pemangkih Kecamatan Tatah Makmur Kalimantan Selatan. Metode yang dilaksanakan pada kegiatan ini berupa penyuluhan tentang manfaat limbah sekam padi dan pelatihan pembuatan bata ringan kepada masyarakat. Hasil kegiatan menunjukkan masyarakat memahami tentang manfaat limbah sekam padi dan mampu menerapkan pengetahuan dan teknologi yang telah diberikan oleh tim pelaksana kegiatan.
\end{abstract}

Kata kunci : sekam padi, serbuk gergajian dan bata ringan

\section{PENDAHULUAN}

Makin meningkatnya kebutuhan perumahan saat ini menyebabkan kebutuhan akan bahan bangunan semakin meningkat pula. Penggunaan batako sebagai bahan bangunan khususnya dinding pada bangunan rumah dan ruko sudah popular serta menjadi pilihan utama masyarakat saat itu namun dari bahan-bahan bangunan ini mempunyai kendala kelemahan tersendiri yaitu berat per meter kubiknya yang cukup besar sehingga berpengaruh terhadap struktur konstruksi bangunan (Budirahardjo dkk, 2014).

Selama ini berbagai penelitian sudah dilakukan tetapi masih belum ditemukan alternatif teknik konstruksi yang efisien serta penyediaan bahan bangunan dalam jumlah besar dan ekonomis tanpa merusak lingkungan. Hal tersebut dapat memberi suatu alternatif untuk memanfaatkan limbahlimbah industri yang dibiarkan begitu saja. Limbah industri untuk bahan 
campuran beton ternyata mampu meningkatkan daya kuat tekan. Bahan tambahan tersebut dapat berupa serbuk gergaji, sekam padi, abu terbang dll.

Kecamatan Tatah Makmur (Gambut) Kalimantan Selatan merupakan salah satu lumbung beras di Kalimantan Selatan. Pada tahun 2013 luas tanam di Kecamatan Gambut sebesar 10,076 ha sehingga luas panennya menjadi 9,714 ha dengan produksi sebanyak 40.566 ton atau dengan rata-rata produksi $41,76 \mathrm{kw} / \mathrm{ha}$. Menurut Sihaputar (2012) dari proses penggilingan padi, biasanya diperoleh sekam $20-30 \%$, dedak 8-12 \%, dan beras giling 50-63,5\% dari bobot awal gabah.

Di Kalimantan Selatan banyak terdapat industri sawmill dimana dari kegiatan industri tersebut dihasilkan limbah berupa sabetan serutan serbuk gergaji. Limbah kayu berupa potongan log maupun sabetan telah dimanfaatkan sebagai papan dan bahan baku partikel, sedangkan limbah berupa serbuk gergaji pemanfaatannya belum optimal (Pari, 2002). Industri penggergajian kayu di Kalimantan Selatan menghasilkan limbah sebesar 40,48\% terdiri atas sebetan $(22,32 \%)$ potongan kayu $(9,39 \%)$ dan serbuk gergaji 8,77

$\%$ (Purwanto, 2009).

Permasalahan utama yang dihadapi oleh mitra binaan adalah melimpahnya limbah sekam padi setelah kegiatan panen setiap tahun. Selama ini sekam padi dibiarkan membusuk atau dibakar yang bisa membahayakan kesehatan dan lingkungan. Penggunaan sekam padi lainnya hanya digunakan untuk pakan ternak, pupuk, media jamur dan lainlain, demikian juga serbuk gergaji hanya digunakan sebagai media tanam sehingga hanya sebagian kecil termanfaatkan. Permasalahan lain adalah kurangnya pengetahuan dan informasi mengenai pemanfaatan sekam padi dan serbuk gergaji menjadi produk bata ringan.

Salah satu solusi pemenuhan kebutuhan bahan bangunan yang semakin meningkat dan melimpahnya limbah sekam padi di areal pertanian adalah dengan memanfaatkan limbah sekam padi dan serbuk gergajian kayu menjadi produk bata ringan sehingga kebutuhan akan bata untuk konstruksi perumahan dapat tersedia dalam jumlah besar. 


\section{METODE PELAKSANAAN}

Metode kegiatan Ipteks bagi Masyarakat dilaksanakan melalui tahapan :

1. Penyuluhan

Kegiatan penyuluhan berupa informasi dan pengetahuan tentang limbah sekam padi dan manfaat limbah sekam padi sebagai bahan campuran untuk pembuatan bata ringan

2. Pelatihan

Kegiatan pelatihan ketrampilan diberikan kepada masyarakat Desa Pemangkih agar mampu menyerap pengetahuan yang diberikan oleh tim pelaksana kegiatan Ipteks bagi Masyarakat. Pelatihan yang diberikan meliputi pembuatan bata ringan dengan teknologi sederhana

\section{Solusi}

Solusi yang ditawarkan oleh tim pelaksana kegiatan adalah:

1) Transfer ipteks melalui ceramah, diskusi, pembimbingan, demonstrasi dan pelatihan mengenai cara pembuatan bata ringan dari limbah sekam padi dan serbuk gergaji

2) Mengenalkan alat dan bahan untuk pembuatan bata ringan beserta fungsi-fungsinya
3) Menjelaskan langkah-langkah pembuatan bata ringan

4) Menciptakan lapangan usaha dari limbah sekam padi dan serbuk gergaji sehingga dapat meningkatkan pendapatan masyarakat

\section{HASIL DAN PEMBAHASAN}

Kegiatan penyuluhan dilaksanakan setelah adanya koordinasi dengan ketua kelompok masyarakat RT. 6 dan Ketua Kelompok Tani Bina Desa RT. 7. Ketua kelompok mitra binaan dan aparat setempat memberikan tanggapan positif tentang kegiatan penerapan ipteks pembuatan bata ringan menggunakan campuran limbah sekam padi serbuk gergajian, karena di Desa Pemangkih terdapat usaha pertanian yang dimiliki masyarakat dan limbah dari pertanian tersebut berupa sekam padi belum dimanfaatkan secara maksimal dan hanya dibiarkan terbuang dan menumpuk begitu saja, sehingga menjadi masalah dalam pengelolaan lingkungan. Dokumentasi kegiatan penyuluhan seperti terlihat pada Gambar 1 dan 2. 

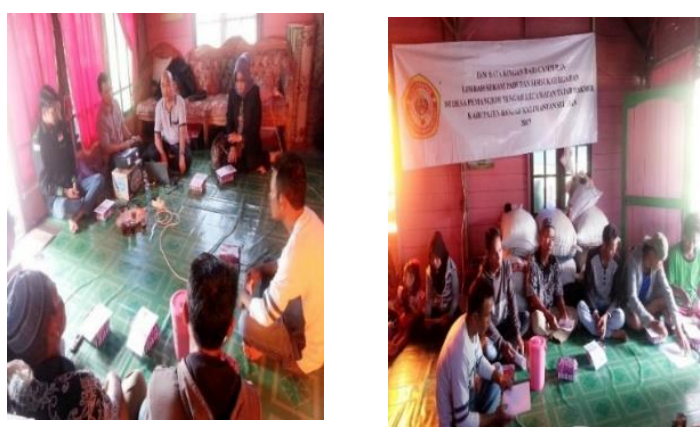

Gambar 1 dan 2. Kegiatan penyuluhan

Sekam padi merupakan lapisan keras yang meliputi kariopsis, terdiri dari belahan lemma dan palea yang saling bertautan, umumnya ditemukan di areal penggilingan padi.

Sebagai bahan bangunan sekam bisa dimanfaatkan sebagai hard board, semen hidraulik, bahan reinforcing karet, industri detergen, industri silika dan industri mineral. Hard board sekam mempunyai sifat tahan air, tahan api dan anti rayap sehingga dapat digunakan untuk bagian dalam atau bagian luar rumah. Pencampuran abu sekam dengan 20-30\% kapur dapat menghasilkan semen hidraulik untuk pembuatan bata tahan asam (http://bbpadi.litbang.pertanian.go.id)

Materi Penerapan Ipteks yang disampaikan kepada mitra binaan yaitu masyarakat RT. 6 dan Kelompok Tani Bina Desa RT. 7 adalah:
1) manfaat limbah sekam padi dan serbuk gergajian yang dapat digunakan sebagai bahan baku pembuatan bata ringan

2) penjelasan cara-cara pembuatan bata ringan dari campuran limbah sekam padi dan serbuk gergajian kayu

3) demonstrasi/peragaan pembuatan bata ringan
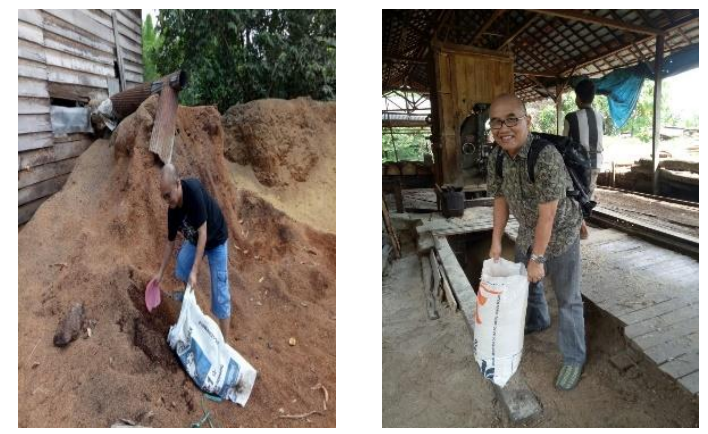

Gambar 3 dan 4. Serbuk Gergajian

Kayu dan Limbah Sekam

Padi

Setelah kegiatan penyuluhan dilaksanakan maka dilanjutkan dengan pelatihan pembuatan bata ringan bersama mitra binaan. Tahapan pembuatan bata ringan secara lengkap adalah sebagai berikut :

1) Menakar limbah sekam padi, limbah gergajian kayu dan gypsum masing-masing 1 ember

2) Menyiapkan air secukupnya

3) Ketiga bahan tersebut kemudian dituangkan ke dalam bak adukan secara berurutan yaitu dimulai dari limbah sekam padi, serbuk 
gergajian kayu, gypsum, kemudian diaduk aduk dan setelah tercampur merata baru ditambahkan air sambil diaduk kembali hingga merata

4) Menyiapkan cetakan dalam kondisi bersih kemudian menuang adukan kira-kira $1 / 3$ cetakan sambil dipadatkan dengan bilah kayu atau sejenisnya, kemudian dituang lagi hingga mencapai kira-kira 2/3 cetakan sambil dipadatkan seperti tahap pertama, lanjutkan hingga penuh dan selalu dipadatkan, khusus yang terakhir harus diratakan pada bagian permukaannya. Menuangkan adukan dan pemadatan harus dengan kecepatan tinggi karena adukan akan mengeras kira-kira 30 menit sejak dicampur dengan air.

5) Hasil cetakan dibiarkan kira-kira 1 jam (untuk pengerasan) kemudian dibuka

6) Setelah dibuka dari cetakan, bata ringan ditempatkan dipalet dan dibiarkan mengering.
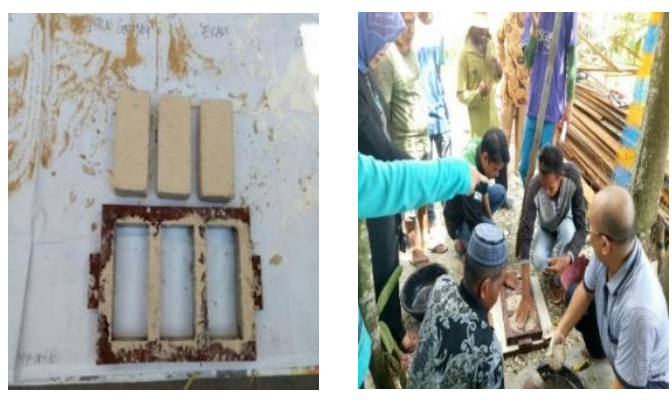

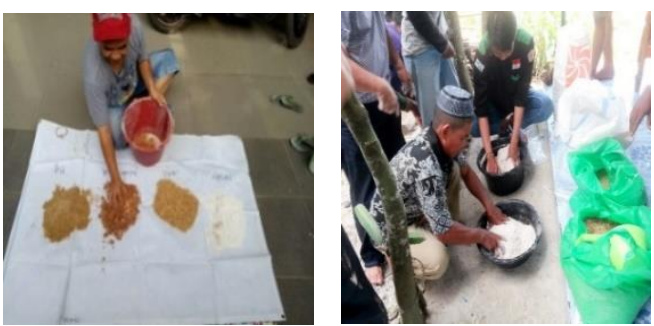

Gambar 5,6,7 dan 8. Pembuatan bata ringan bersama mitra binaan Semua tahapan kegiatan mulai dari sosialisasi, penyuluhan dan pelatihan melibatkan secara aktif khalayak sasaran. Masyarakat binaan yaitu kelompok masyarakat RT. 6 dan RT. 7 (Kelompok Tani Bina Desa) antusias mengikuti kegiatan tersebut karena selama ini limbah sekam padi belum mereka manfaatkan, tetapi melalui pengetahuan yang disampaikan tim pelaksana ternyata limbah sekam padi tersebut dapat dibuat bata ringan yang mempunyai nilai ekonomis. Kegiatan penyuluhan diharapkan dapat memberi manfaat dan sumber pengetahuan bagi masyarakat yang tergabung dalam kelompok tani agar lebih kreatif memanfaatkan limbah yang tersedia berlimpah di desa mereka menjadi produk yang bernilai ekonomis.

Melalui kegiatan pengabdian kepada masyarakat ini secara umum petani sudah mengerti dan memahami 
cara pembuatan bata ringan dari campuran limbah sekam padi dan limbah gergajian kayu. Hal tersebut terlihat pada saat pelatihan pembuatan bata ringan mereka mampu membuat bata ringan sesuai dengan teknik yang telah diajarkan oleh tim pelaksana.

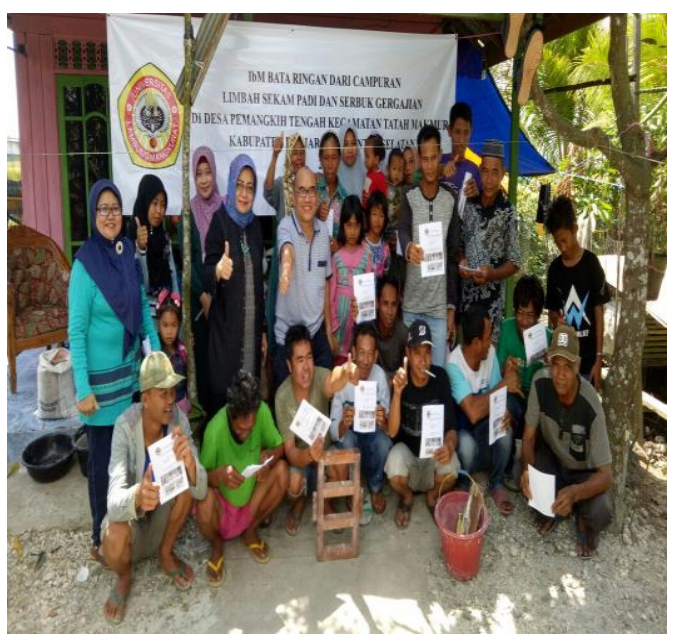

Gambar 9. Tim Pelaksana IbM dan Mitra Binaan

Pada akhir kegiatan sosialisasi dan penyuluhan pembuatan bata ringan dari campuran limbah sekam padi dan limbah serbuk gergajian dilakukan penyerahan alat cetak kepada mitra binaan yaitu Kelompok masyarakat RT. 6 dan Kelompok Tani Bina Desa RT. 7 agar masyarakat dapat membuat bata ringan dengan alat yang telah tersedia. Alat cetak tersebut secara simbolis diserahkan kepada Kepala RT. 7 Bapak Busiri seperti terlihat pada gambar 10.

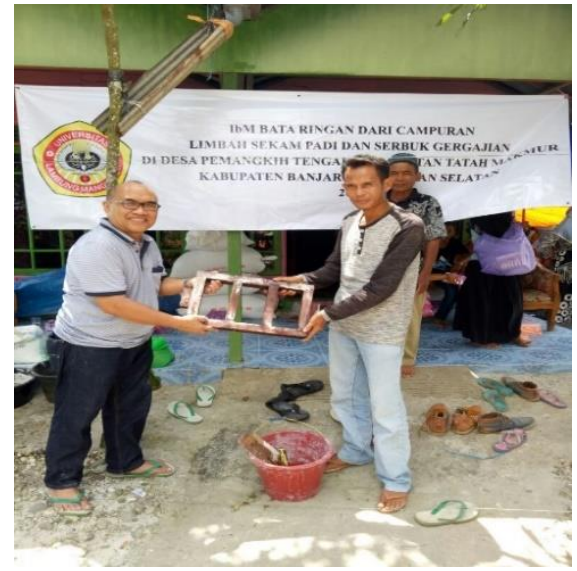

Gambar 10. Penyerahan Alat cetak bata ringan

\section{KESIMPULAN}

Kesimpulan yang diperoleh dari kegiatan Ipteks bagi Masyarakat ini adalah sebagai berikut :

1. Pembuatan bata ringan dapat mengatasi permasalahan limbah sekam padi dan serbuk gergajian.

2. Kegiatan Ipteks bagi masyarakat menghasilkan luaran alat cetak bata ringan dan produk bata ringan

3. Petani mampu membuat bata ringan dari limbah sekam padi dan limbah serbuk gergajian kayu

\section{UCAPAN TERIMA KASIH}

Terima kasih disampaikan kepada Kementerian Riset, Teknologi dan Pendidikan Tinggi yang telah 
mendanai kegiatan ini melalui Skema

Ipteks bagi Masyarakat Tahun 2017.

\section{DAFTAR PUSTAKA}

Budirahardjo, S, Kristiawan, A, dan Wardani, A., 2014. Pemanfaatan Sekam Padi Pada Batako. Prosiding SNSTKES Tahun 2014. Fakultas Teknik Universitas Wahid Hasyim Semarang

Sihaputar, D., 2012. Teknologi Briket Sekam Padi. Balai Pengkajian Teknologi Riau. http://riau.litbang.deptan.go.id/i
nd/images/stories/PDF/teknolog ibriket.pdf

Pari, G., 2003. Teknologi Alternatif Pemanfaatan Limbah Industri Pengolahan Kayu. Makalah Falsafah Sains. Jakarta

Purwanto, D., 2009. Analisa Jenis Limbah Kayu pada Industri Pengolahan Kayu di Kalimantan Selatan. Jurnal Riset Industri Hasil Hutan Vol. 1 No.1

BBPTP, 2017. Manfaat Sekam Padi. http://bbpadi.litbang.pertanian.g o.id/index.php/berita/infoteknologi/content/419-manfaat$\underline{\text { sekam }}$ 